DOI: 10.12957/demetra.2018.36675

\title{
Sobre o uso do número de citações em periódicos para avaliar Ciência - em especial, citações de curto prazo
}

\section{On the use of the number of citations in journals to evaluate Science - short-term citations, particularly}

Um dos procedimentos mais valorizados para avaliação no campo científico brasileiro, com destaque para a Biomedicina, corresponde ao uso do número de citações de um periódico em curto período de tempo. Recentemente, no processo avaliativo dos programas de pós-graduação, a área "Nutrição" na CAPES adotou as citações de revistas científicas nos últimos dois anos como referência principal - ou única - para definir o valor das publicações dos pesquisadores que atuam nesse campo de formação de mestres e doutores e de produção de conhecimentos e saberes.

Identifica-se, já há algum tempo, importante volume de críticas a esses procedimentos que tomam específicas métricas para estabelecer quem tem mais ou menos valor no sistema de pósgraduação brasileiro - quem vai receber maior ou menor nota e, consequentemente, mais ou menos dinheiro, mais ou menos capital científico. Propostas diversas vêm sendo apresentadas por diversos setores da pesquisa, buscando novas perspectivas para tais avaliações, ainda na expectativa de que venham a ser adotadas com a ênfase necessária.

Enquanto essas regras permanecem, alguns estudos trazem resultados bem interessantes, reforçando a linha argumentativa acima aludida. É o caso da postagem de Lilian Nassi-Calò ${ }^{1}$ no blog "SciELo em Perspectiva", sob o título "A miopia dos indicadores bibliométricos". ${ }^{2}$ Parte a autora da ideia de que, diante de grande número de pesquisadores, projetos, artigos e similares a serem considerados, indicadores bibliométricos facilitam os trabalhos dos avaliadores, tornandoos simples (ou simplistas) - travessia na qual se fazem presentes também os avaliados, quando compartilham de tais valores, reforçando-os, inclusive. Nas palavras da autora: "A utilização de

1 Lilian Nassi-Calò é química pelo Instituto de Química da USP e doutora em Bioquímica pela mesma instituição; foi bolsista da Fundação Alexander von Humboldt em Wuerzburg, Alemanha. Após concluir seus estudos, foi docente e pesquisadora no IQ-USP. Trabalhou na iniciativa privada como química industrial e atualmente é coordenadora de Comunicação Científica na BIREME/OPAS/OMS e colaboradora do SciELO.

2 NASSI-CALÒ, L. A miopia dos indicadores bibliométricos [online]. SciELO em Perspectiva, 2017 [viewed 27 August 2018]. Available from: https://blog.scielo.org/blog/2017/06/01/a-miopia-dos-indicadores-bibliometricos/. 
indicadores bibliométricos para avaliação da ciência é uma prática ubíqua, a despeito de não existir uma relação inequívoca entre citações e qualidade, impacto ou mérito científico". Acentua-se ainda mais "[q]uando se considera a inovação - característica inerente da pesquisa científica - [onde] a relação é ainda mais desconexa”.

A pesquisadora apresenta resultados de artigo divulgado na revista Nature por Stephan e colaboradores, ${ }^{3}$ considerando a hipótese de que o uso excessivo de citações nos últimos dois ou três anos não favorece ou mesmo desencoraja a publicação de estudos inovadores.

Diz Nassi-Calò:

[...] os autores analisaram as citações no Web of Science de mais de 660 mil artigos publicados entre 20012015 categorizados em pesquisa com alto, moderado e nenhum grau de inovação. Como proxy para grau de inovação, os pesquisadores avaliaram a lista de referências dos artigos em busca de padrões insólitos de combinação. Desta análise, os autores chegaram à conclusão de que os artigos altamente inovadores levam mais tempo para serem citados em comparação aos medianamente inovadores e aos não inovadores. Entre os artigos altamente inovadores, dois tipos de comportamento foram observados: ou tornavam-se artigos altamente citados - as citações começam a aumentar após 3-4 anos e se mantêm em ritmo crescente até 15 anos após a publicação - ou eram ignorados, em comparação aos artigos com nenhum grau de inovação. Porém, é importante notar que nos 3 anos após a publicação, a probabilidade de um artigo altamente inovador estar entre os $1 \%$ mais citados é inferior à probabilidade para artigos com nenhum grau de inovação. Isso levou os autores a concluir que o sistema atual de avaliação da pesquisa subestima trabalhos que possivelmente terão alto impacto na avaliação em longo prazo. É importante também ressaltar que artigos que se revelaram de alto impacto no decorrer do tempo foram publicados em periódicos de menor FI.

As palavras da equipe de Stephan são ilustrativas dos desdobramentos adversos que o uso desses procedimentos avaliativos centrados em indicadores de citação - em especial, os de curto prazo - pode trazer: "[...] quanto mais estamos ligados a indicadores bibliométricos de curto prazo, mais longe estamos de recompensar a pesquisa com alto potencial de ir além das fronteiras - e aqueles que o fazem".

Ao final de sua postagem, um conjunto de recomendações dirigidas a pesquisadores, agências de fomento, pareceristas, editores e universidade é elencado, com destaque para a importância e a necessidade da valorização efetiva de perspectivas quantitativas e qualitativas, de modo a evitar que sejam penalizadas proposições com maior potencial de ampliar os horizontes da ciência.

Shirley Donizete Prado e Fabiana Bom Kraemer

Editoras

3 STEPHAN, P., VEUGELERS, R. and WANG, J. Reviewers are blinkered by bibliometrics. Nature[online]. 2017, vol. 544, no. 7651, pp. 411-412 [viewed 14 May 2017]. DOI: 10.1038/54441la. Available from: http:// www.nature.com/news/reviewers-are-blinkered-by-bibliometrics-1.21877 